\title{
Ethnic background and CYP2D6 genetic polymorphisms in Costa Ricans
}

\author{
Carolina Céspedes-Garro ${ }^{1,2}$, Gerardo Jiménez-Arce ${ }^{1}$, María-Eugenia G. Naranjo ${ }^{2}$, Ramiro \\ Barrantes $^{1 *}$, Adrián LLerena ${ }^{2 *} \&$ CEIBA.FP Consortium of the Ibero-American Network of \\ Pharmacogenetics \& Pharmacogenomics RIBEF. \\ 1. Genetics Section, School of Biology, University of Costa Rica, 2060 San Pedro, San José, Costa Rica; \\ ccg004@gmail.com, gerardo.jimenez@ucr.ac.cr, ramiro.barrantes@ucr.ac.cr \\ 2. CICAB Clinical Research Centre, Extremadura University Hospital and Medical School, Badajoz, Spain; \\ megleznaranjo@gmail.com, allerena@unex.es \\ * Correspondence
}

Received 14-I-2014. Corrected 28-VI-2014. Accepted 29-VII-2014.

\begin{abstract}
CYP2D6 differences have already been demonstrated within Latin American populations by the CEIBA.FP Consortium of the Ibero-American Network of Pharmacogenetics (RIBEF, as per the acronym in Spanish). However, within the population of Costa Rica, no research has been conducted until now, even though this population has a trihybrid component ancestry that represents an interesting condition. Thus, the present study was aimed to determine the frequency of Ultra-rapid Metabolizers (UMs) and Poor Metabolizers (PMs) in a Costa Rican population, as well as to determine whether there are differences in the CYP2D6-predicted phenotype frequencies among three Costa Rican groups with different ethnic backgrounds. Additionally, these frequencies of PMs and UMs obtained were compared with Ibero-American populations published data. Finally, we also aimed to describe allele frequencies among different Costa Rican ethnic groups. This research has been undertaken within the framework of the RIBEF CEIBA Consortium studies on Latin American populations. A total of 385 individuals were included in the study: 139 mestizos, 197 Amerindians, and 49 Afro-Caribbeans. CYP2D6 genotypes were determined by XL-PCR and Real-Time PCR. The CYP2D6 variant alleles *2, *3, *4, $* 5, * 6, * 10, * 17, * 29, * 35$ and $* 41$ were also determined. For the entire Costa Rican population, the frequency of PMs and UMs was 6\% and 6.5\%, respectively. The percentage of UMs in the mestizo population was higher than in the Amerindian population. CYP2D6 UMs vary from $3.6 \%$ to $10.1 \%$ and PMs from $1.4 \%$ to $10.2 \%$ among three Costa Rican groups. The highest frequencies of UMs (10.1\%) and PMs (10.2\%) were found in the mestizo and Amerindian populations, respectively. In conclusion, the frequencies of UMs and PMs for CYP2D6 varied widely across the mestizo, Amerindian and Afro-Caribbean Costa Rican populations. Future research in this population should be oriented to identify new CYP2D6 variants through sequencing methods, as well as to determine CYP2D6 phenotype, in order to establish the phenotype-genotype relation. Finally, further studies involving genetic markers of ancestry are needed in the Costa Rican population. Rev. Biol. Trop. 62 (4): 16591671. Epub 2014 December 01.
\end{abstract}

Key words: CYP2D6, Costa Rica, Amerindian, Afro-Caribbean, mestizo, populations, Poor Metabolizers, Ultrarapid Metabolizers.

CYP2D6 is involved in the metabolism of widely used drugs, such as antidepressants, antipsychotics, antihypertensives, analgesics, and beta-blockers (Ingelman-Sundberg, 2005). The CYP2D6 gene, located on chromosome $22 q 13.1$, is highly polymorphic, with alleles causing absent, reduced, normal and increased catalytic activity (CYP Alleles Nomenclature Database).

Inter-ethnic differences in such cytochrome $\mathrm{P} 450$ polymorphism might be partially responsible for the variations in drug disposition among populations. During the $16^{\text {th }}$ century, people from the Iberian Peninsula arrived to different places of America leading current Costa Rican, Latin American, and Caribbean populations to have different degrees of admixture (Gaedigk et al., 2010; Llerena et 
al., 2012; Montané-Jaime, Lalla, Steimer, \& Gaedigk, 2013). Latin American populations are products of a process of admixture, mainly including groups of Amerindian, European and African ancestry (Sans, 2000). The Costa Rican population has been described as having estimated mean ancestry proportions for European, Amerindian, and African components of $54 \%, 32 \%$, and $13 \%$, respectively (Segura-Wang, Raventós, Escamilla, \& Barrantes, 2010). Therefore, it could be of relevance to determine potential differences across the multi-ethnic Costa Rican population.

A high frequency of Ultra-rapid Metabolizers (UMs) has been previously described in Spanish population (Llerena, Dorado, \& Peñas-Lledó, 2009; Peñas-Lledó et al., 2012). Given the Iberian Peninsula's influence on the hybrid population, we hypothesized that a high frequency of UMs would be present in the mestizo population. It was also hypothesized that high frequencies of CYP $2 D 6^{*} 17$ would be found in the Afro-Caribbean population due to their African ancestry and CYP $2 D 6^{*} 10$ within the Amerindian population due to their Asian ancestry (Bradford, 2002).

In Central American countries, there are just a few studies in Panama (Arias et al., 1986; Arias, Jorge, Lee, Barrantes, \& Inaba, 1988), Nicaragua (Llerena et al., 2012; Llerena et al., 2013) and Costa Rica (reporting some alleles of a Costa Rican Amerindian population) (Jorge \& Arias, 1995). CYP2D6 genetic polymorphisms studies have been carried out in Latin American countries supported by the CEIBA. FP Consortium of the Ibero-American Network of Pharmacogenetics \& Pharmacogenomics (RIBEF) (de Andrés et al., 2013; Rodeiro et al., 2012), including Ecuadorians (Dorado et al., 2012), Mexicans (Sosa-Macías, Dorado, Alanis-Bañuelos, Llerena, \& Lares-Asseff, 2010) and Cubans (González et al., 2008; Llerena et al., 2012; Llerena et al., 2013; Peñas-Lledó, Dorado, Pacheco, González, \& Llerena, 2009). However, this will constitute the first report of a Costa Rican population including groups from different ethnic backgrounds.
The present study aimed to determine the frequency of UMs and Poor Metabolizers (PMs) in a Costa Rican population, as well as to determine whether there are differences in CYP2D6-predicted phenotype frequencies among three Costa Rican groups with different ethnic backgrounds. Additionally, the frequency of PMs and UMs obtained in this study was compared with published data from Ibero-American populations, and finally, this study also aimed to describe allele frequencies among different Costa Rican ethnic groups.

\section{MATERIALS AND METHODS}

Subjects: The study comprised 385 healthy individuals belonging to three ethnic groups: Amerindian ( $\mathrm{n}=197)$, Afro-Caribbean $(\mathrm{n}=49)$ and mestizo $(\mathrm{n}=139)$.

The DNA samples were obtained from a DNA biobank of the School of Biology of the University of Costa Rica. The samples were collected and stored after approval from review boards of the University of Costa Rica, and have been widely studied (Azofeifa et al., 2004; Barrantes et al., 1990; Barrantes, Smouse, Neel, Mohrenweiser, \& Gershowitz, 1982; Barrantes, 1993a, 1993b; Morera, Barrantes, \& Marin-Rojas, 2003; Morera \& Barrantes, 2004; Reich et al., 2012; Santos, Ward, \& Barrantes, 1994; Thompson, Neel, Smouse, \& Barrantes, 1992; Wang et al., 2007, 2008). All the samples were already classified according to the ethnic origin and previous studies (see inclusion criteria), codified, and stored with an ID. Demographic data of these populations are available elsewhere (Barrantes, 1989; Madrigal, 2006; Morera et al., 2003).

The inclusion criteria were:

- Phenotype features: For the Amerindian population, the criteria were copper-colored skin, straight hair, slanted eyes, and short stature; in the Afro-Caribbean population, dark skin, curly hair, flat nose, and prominent cheekbones were the criteria; the Mestizo population comprised all those 
subjects not included in any of the aforementioned groups.

- Places of residence: For the Amerindian group, the places of residence were Matambu Indian locality (Chorotega), the South and the Pacific area (Guaymi), the Atlantic Talamanca and the Pacific area (Cabecar), the Talamanca area (Bribri), the Quitirrisi and Zapaton Indian localities (Huetar), and the Margarita and Tonjibe Guatuso Indian localities (Guatuso or Maleku). The samples of the AfroCaribbean population were collected from volunteers living in the Atlantic coastal region of Limon. The mestizo population was selected from people living in the Guanacaste region, and in the Western or Central Valley of Costa Rica (Fig. 1). The inclusion of an individual in a group excluded that individual from being part of any other population.
- Genetic markers such as blood group systems: $\mathrm{ABO}(\mathrm{O}$ for Amerindians and $\mathrm{B}$ for the Afro-Caribbeans), rhesus, MNS, P, Kell, Kidd, Duffy, Diego, and Lewis; plasmatic protein systems (albumin, transferrin, haptoglobin, and ceruloplasmin) (Barrantes et al., 1990; Bieber, Bieber, Rodewald, \& Barrantes, 1996); single nucleotide polymorphisms (SNPs) (Herrmann et al., 2002); microsatellites (Wang et al., 2007); mitochondrial DNA (Santos et al., 1994) and chromosome Y (RuizNarváez et al., 2005).

Genotyping procedure: For genotyping, the CEIBA.FP Consortium methodology was followed. To detect the presence of allelic variants harboring a CYP2D6*5 gene deletion or a duplication, long range (XL)-PCR was performed as described in detail elsewhere (Fig. 2) (Dorado et al., 2005). Subjects

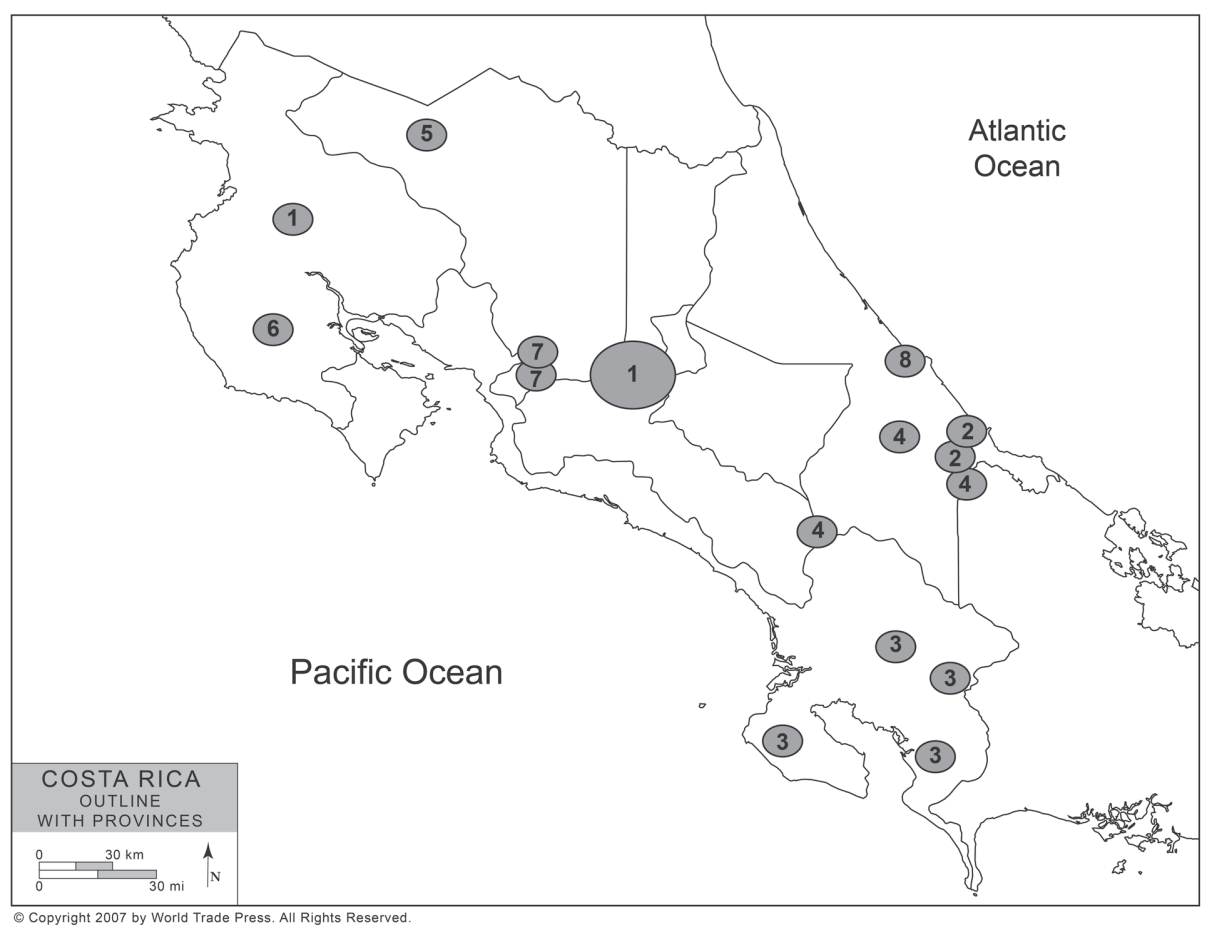

Fig. 1. The approximate geographic locations of the Costa Rican populations studied. 1: mestizo population. 2: Bribri. 3 : Guaymi. 4: Cabecar. 5: Guatuso. 6: Chorotega. 7: Huetar. 8: Afro-Caribbean population. 


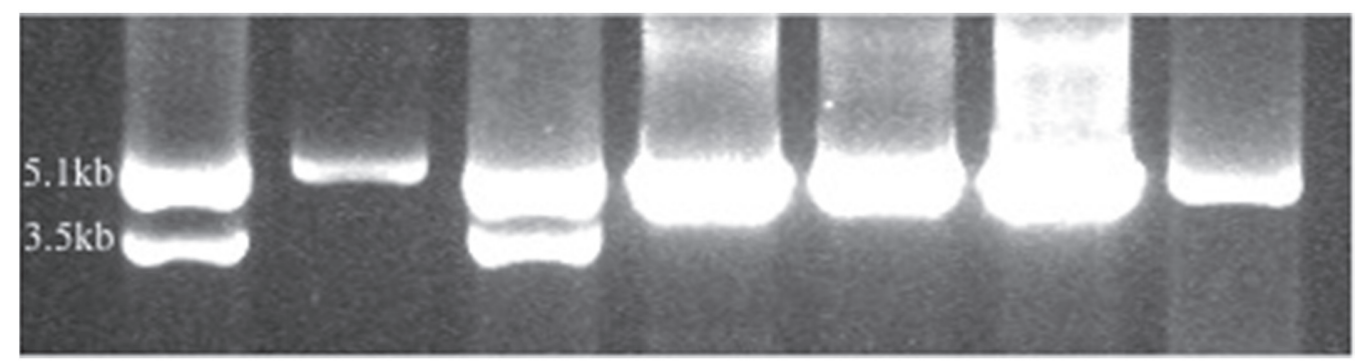

Fig. 2. PCR output for $C Y P 2 D 6 * 5$ on a $0.8 \%$ agarose gel. Identification of lanes (from left to right) 1: positive control $(5.1 \mathrm{~kb}+3.5 \mathrm{~kb}), 2$ and $4-7$ : samples negative for deletion (wild-type; $5.1 \mathrm{~kb})$ and 3 : sample positive for deletion $\left(C Y P 2 D 6^{*} 5\right)$.

positive for a duplication or deletion were further characterized for gene copy number with the TaqMan assay Hs00010001_cn, which specifically amplifies exon 9 sequences and does not amplify CYP2D7 or CYP2D8 pseudogenes or $C Y P 2 D 6 / C Y P 2 D 7$ hybrids alleles carrying $C Y P 2 D 7$ exon 9 sequences. Genotype analysis for the CYP2D6*2 (-1584 C>G), *3 $(2549 \mathrm{~A}>\mathrm{del}), * 4 \quad(100 \mathrm{C}>\mathrm{T}, 1846 \mathrm{G}>\mathrm{A}), \quad * 6$ $(1707 \mathrm{~T}>\mathrm{del}), \quad * 10 \quad(100 \mathrm{C}>\mathrm{T}), \quad * 17 \quad(1023$ $\mathrm{C}>\mathrm{T}), * 29(3183 \mathrm{G}>\mathrm{A}), * 35(-1584 \mathrm{C}>\mathrm{G}$ and $31 \mathrm{G}>\mathrm{A})$, and $* 41(2988 \mathrm{G}>\mathrm{A})$ allelic variants was carried out on genomic DNA, using commercially available TaqMan assays as previously described (Dorado et al., 2012). To discriminate among $C Y P 2 D 6 * 1 x N, * 2 x N, * 4 x N$ and $* 10 x N$ alleles, a $10 \mathrm{~kb}$ long XL-PCR fragment was generated from duplication-positive subjects and tested for respective SNPs by an established PCR-RFLP approach (Dorado et al., 2005).

Predicted hydroxylation capacity group: In order to extrapolate genetic data to metabolic phenotype information, an activity score was utilized as previously described (Gaedigk et al., 2008; Llerena et al., 2012).

Zero value was assigned to $C Y P 2 D 6^{*} 3$, $* 4, * 4 X N, * 5, * 6$ variants; 0.5 to each copy of CYP2D6*10, *17, *29, *41 alleles; one was assigned to CYP2D6 wt, *2, *35, and more than two (depending on the number of copies) to the multiplication of the active alleles ( $w t x N$, $* 2 x N$ ). Individuals with zero active genes were classified as poor metabolizers (PMs), and those with more than two active gene copies were classified as Ultra-rapid Metabolizers (UMs) (Gaedigk et al., 2008; Llerena et al., 2012).

The differences in CYP2D6 allele frequencies were compared using the $\mathrm{X}^{2}$-test and/or Fisher's exact test. P-values $<0.05$ were regarded as statistically significant. Hardy-Weinberg equilibrium was determined by comparing the genotype frequencies with the expected values using a contingency table $\mathrm{X}^{2}$ statistic with Yate's correction. Statistical analyses were performed using the STATISTICA 4.3 (StatSoft, Tulsa, OK, USA) and GraphPad Prism 3.02 (GraphPad Software, San Diego, CA, USA) software.

\section{RESULTS}

CYP2D6 allele frequencies are given in table 1. Multiplications of active genes ( wtxN, $* 2 x N$ ) were present in 15 individuals of the mestizo population and in seven of each of the Amerindian and Afro-Caribbean populations (Table 1).

Null activity alleles *4 and *5 frequencies in the Amerindian population were higher (22.6\% and $4.8 \%$, respectively) than in the mestizo group (10.4\% and $3.2 \%$, respectively; $\mathrm{p}<0.05$ ) (Table 1). The frequencies of alleles with decreased activity $(* 17$ and $* 29)$ in the Afro-Caribbean population were higher (18.4\% and $11.2 \%$ ) than in the other two populations $(\mathrm{p}<0.05)$, and the CYP2D $6^{*} 10$ frequency in the 
TABLE 1

CYP2D6 allele and active gene frequencies in three Costa Rican ethnic groups studied

\begin{tabular}{|c|c|c|c|c|c|c|c|c|c|c|c|}
\hline \multirow{3}{*}{ Allele } & \multicolumn{2}{|c|}{ Costa Rica } & \multicolumn{2}{|c|}{ Mestizo } & \multicolumn{3}{|c|}{ Amerindian } & \multicolumn{4}{|c|}{ Afrocaribbean } \\
\hline & \multirow{2}{*}{$\begin{array}{c}n=385 \\
370\end{array}$} & \multirow{2}{*}{$\begin{array}{c}\text { Frequency } \\
0.481\end{array}$} & \multirow{2}{*}{$\begin{array}{c}n=278 \\
134\end{array}$} & \multirow{2}{*}{$\begin{array}{c}\text { Frequency } \\
0.482\end{array}$} & \multirow{2}{*}{$\begin{array}{c}n=394 \\
199\end{array}$} & \multicolumn{2}{|l|}{ Frequency } & \multirow{2}{*}{$\begin{array}{c}\mathrm{n}=98 \\
37\end{array}$} & \multicolumn{3}{|c|}{ Frequency } \\
\hline & & & & & & 0.505 & & & 0.378 & $*$ & $* *$ \\
\hline$* 2$ & 115 & 0.149 & 50 & 0.180 & 59 & 0.150 & & 6 & 0.061 & $*$ & $* *$ \\
\hline$* 3$ & 5 & 0.006 & 4 & 0.014 & 0 & 0.000 & & 1 & 0.010 & & \\
\hline$* 4$ & 122 & 0.158 & 29 & 0.104 & 89 & 0.226 & $*$ & 4 & 0.041 & & $* *$ \\
\hline *5 & 32 & 0.042 & 9 & 0.032 & 19 & 0.048 & * & 4 & 0.041 & & \\
\hline$* 6$ & 2 & 0.003 & 2 & 0.007 & 0 & 0.000 & $*$ & 0 & 0.000 & & \\
\hline$* 10$ & 7 & 0.009 & 3 & 0.011 & 1 & 0.003 & & 3 & 0.031 & & $* *$ \\
\hline$* 17$ & 31 & 0.040 & 6 & 0.022 & 7 & 0.018 & & 18 & 0.184 & $*$ & $* *$ \\
\hline *29 & 17 & 0.022 & 4 & 0.014 & 2 & 0.005 & & 11 & 0.112 & $*$ & $* *$ \\
\hline *35 & 5 & 0.006 & 1 & 0.004 & 3 & 0.008 & & 1 & 0.010 & & \\
\hline$* 41$ & 26 & 0.034 & 17 & 0.061 & 8 & 0.020 & * & 1 & 0.010 & & \\
\hline$w t x N$ & 16 & 0.021 & 8 & 0.029 & 4 & 0.010 & & 4 & 0.041 & & \\
\hline$* 2 x N$ & 13 & 0.017 & 7 & 0.025 & 3 & 0.008 & & 3 & 0.031 & & \\
\hline$* 4 x N$ & 6 & 0.008 & 4 & 0.014 & 0 & 0.000 & $*$ & 2 & 0.020 & & $* *$ \\
\hline$* 10 x N$ & 2 & 0.003 & 0 & 0.000 & 0 & 0.000 & & 2 & 0.020 & & $* *$ \\
\hline$* 17 x N$ & 1 & 0.001 & 0 & 0.000 & 0 & 0.000 & & 1 & 0.010 & & \\
\hline \multicolumn{12}{|c|}{ Active genes ${ }^{\mathrm{a}}$} \\
\hline 0 & & 0.060 & 2 & 0.014 & 20 & 0.102 & * & 1 & 0.020 & & \\
\hline 0.5 & & 0.052 & 10 & 0.072 & 6 & 0.030 & & 4 & 0.082 & & \\
\hline 1 & & 0.270 & 32 & 0.230 & 62 & 0.315 & & 8 & 0.163 & & \\
\hline 1.5 & & 0.114 & 18 & 0.129 & 12 & 0.061 & & 16 & 0.327 & & \\
\hline 2 & & 0.439 & 63 & 0.453 & 90 & 0.457 & & 16 & 0.327 & & \\
\hline$>2$ & & 0.065 & 14 & 0.101 & 7 & 0.036 & $*$ & 4 & 0.082 & & \\
\hline
\end{tabular}

n: number of subjects. ${ }^{*} \mathrm{p}<0.05$ compared with mestizo by Fisher's exact Test. ${ }^{*} \mathrm{p}<0.05$ compared with the Amerindian group by Fisher's exact Test. ${ }^{\text {a } C Y P} 2 D 6 * 3, * 4, * 4 X N, * 5, * 6$ variants were assigned the value of zero; $C Y P 2 D 6 * 10, * 17, * 29$, $* 41$ alleles were assigned 0.5 for each copy; CYP2D6 wt, *2, *35 were assigned one, and the multiplication of the active alleles ( $w t x N, * 2 x N$ ) were assigned $\geq 2$ (depending on the number of copies).

Amerindian population $(0.3 \%)$ was lower than in the Afro-Caribbean $(3.1 \% ; \mathrm{p}<0.05)$.

The CYP2D6 frequencies for each activity score group are given in table 1 . The entire Costa Rican population frequency of PMs and UMs were $6 \%$ and $6.5 \%$ respectively.

As expected, the percentage of UMs in the mestizo population $(10.1 \%)$ was higher than in the Amerindian population $(3.6 \%, \mathrm{p}<0.05)$ (Table 1). However, the frequency of individuals classified as PMs (zero active genes) was higher in Amerindians (10.2\%) than in the mestizo population $(1.4 \%, \mathrm{p}<0.05)$. The frequency of UMs $(8.2 \%)$ and PMs $(2 \%)$ of the Afro-Caribbean population was not different to any of the Costa Rican populations studied.
The frequencies of CYP2D6 genotypes are listed in table 2 . The mestizo population showed more diversity concerning genotypes in comparison with the other Costa Rican populations studied. In all three groups, the most frequently found CYP2D6 genotypes belonged to the classification of two active genes (Table 2). Published data from Latin American populations is used to compare results with the Costa Rican populations (Table 3).

\section{DISCUSSION}

To the best of our knowledge, this is the first study in a Costa Rican population that 
TABLE 2

Frequencies of cytochrome P450 2D6 (CYP2D6) genotypes in three Costa Rican groups $(\mathrm{n}=385)$

\begin{tabular}{|c|c|c|c|c|c|c|c|c|c|c|}
\hline \multirow{3}{*}{ Genotype } & \multirow{3}{*}{$\begin{array}{l}\text { Activity } \\
\text { score }\end{array}$} & \multicolumn{3}{|c|}{ Mestizo } & \multicolumn{3}{|c|}{ Amerindian } & \multicolumn{3}{|c|}{ Afro-Caribbean } \\
\hline & & \multicolumn{3}{|c|}{$\mathrm{n}=139$} & \multicolumn{3}{|c|}{$\mathrm{n}=197$} & \multicolumn{3}{|c|}{$\mathrm{n}=49$} \\
\hline & & $\mathrm{n}$ & Frequency & Expected freq & $\mathrm{n}$ & Frequency & Expected freq & $\mathrm{n}$ & Frequency & Expected freq \\
\hline$* 4 / * 4$ & 0 & 1 & 0.007 & 0.011 & 13 & 0.066 & 0.051 & 0 & - & 0.002 \\
\hline$* 4 / * 5$ & 0 & 1 & 0.007 & 0.007 & 7 & 0.036 & 0.022 & 0 & _- & \\
\hline$* 3 / * 4 \times 3$ & 0 & 0 & _ & & 0 & 0.000 & & 1 & 0.020 & \\
\hline$* 3 / * 41$ & 0.5 & 1 & 0.007 & 0.002 & 0 & - & & 0 & _ & \\
\hline$* 4 * 10$ & 0.5 & 0 & - & & 1 & 0.005 & 0.001 & 0 & - & \\
\hline$* 4 / * 17$ & 0.5 & 2 & 0.014 & 0.005 & 4 & 0.020 & 0.008 & 0 & _- & \\
\hline$* 4 / * 29$ & 0.5 & 0 & - & & 0 & - & & 1 & 0.020 & 0.009 \\
\hline$* 4 / * 41$ & 0.5 & 3 & 0.022 & 0.013 & 1 & 0.005 & 0.009 & 0 & - & \\
\hline$* 5 / * 17$ & 0.5 & 0 & _- & & 0 & _ & & 2 & 0.041 & 0.015 \\
\hline$* 5 / * 29$ & 0.5 & 0 & _- & & 0 & - & & 1 & 0.020 & 0.009 \\
\hline$* 5 / * 41$ & 0.5 & 1 & 0.007 & 0.004 & 0 & _- & & 0 & _ & \\
\hline$* 6 / * 41$ & 0.5 & 1 & 0.007 & 0.001 & 0 & _- & & 0 & _- & \\
\hline$* 4 \times 2 / * 10$ & 0.5 & 2 & 0.014 & 0.000 & 0 & - & & 0 & - & \\
\hline$w t / * 3$ & 1 & 1 & 0.007 & 0.013 & 0 & - & & 0 & _- & \\
\hline$w t / * 4$ & 1 & 16 & 0.115 & 0.100 & 33 & 0.168 & 0.228 & 0 & 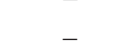 & \\
\hline$w t / * 5$ & 1 & 4 & 0.029 & 0.031 & 10 & 0.051 & 0.048 & 1 & 0.020 & 0.031 \\
\hline$* 2 / * 4$ & 1 & 5 & 0.036 & 0.037 & 16 & 0.081 & 0.068 & 0 & _ & \\
\hline$* 2 / * 5$ & 1 & 3 & 0.022 & 0.012 & 2 & 0.010 & 0.014 & 0 & _- & \\
\hline$* 2 / * 6$ & 1 & 1 & 0.007 & 0.003 & 0 & _- & & 0 & _- & \\
\hline$* 4 / * 35$ & 1 & 0 & - & & 1 & 0.005 & 0.004 & 0 & - & \\
\hline$* 10 / * 17$ & 1 & 0 & _- & & 0 & - & & 2 & 0.041 & 0.011 \\
\hline$* 17 / * 17$ & 1 & 0 & _- & & 0 & _ & & 2 & 0.041 & 0.034 \\
\hline$* 17 / * 29$ & 1 & 0 & 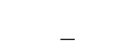 & & 0 & - & & 2 & 0.041 & 0.041 \\
\hline$w t / * 4 x N^{\#}$ & 1 & 2 & 0.014 & 0.013 & 0 & - & & 0 & _ & \\
\hline$* 2 / * 4 X 3$ & 1 & 0 & _ & & 0 & _- & & 1 & 0.020 & \\
\hline$w t / * 10$ & 1.5 & 0 & - & & 0 & - & & 1 & 0.020 & 0.023 \\
\hline$w t / * 17$ & 1.5 & 4 & 0.029 & 0.021 & 1 & 0.005 & 0.018 & 4 & 0.082 & 0.139 \\
\hline$w t / * 29$ & 1.5 & 3 & 0.022 & 0.013 & 0 & - & 0.005 & 6 & 0.122 & 0.085 \\
\hline$w t / * 41$ & 1.5 & 6 & 0.043 & 0.059 & 6 & 0.030 & 0.020 & 1 & 0.020 & 0.008 \\
\hline$* 2 / * 17$ & 1.5 & 0 & - & & 2 & 0.010 & 0.005 & 1 & 0.020 & 0.022 \\
\hline$* 2 / * 29$ & 1.5 & 0 & - & & 2 & 0.010 & 0.002 & 0 & - & \\
\hline$* 2 / * 41$ & 1.5 & 4 & 0.029 & 0.022 & 1 & 0.005 & 0.006 & 0 & _- & \\
\hline$* 10 / * 35$ & 1.5 & 1 & 0.007 & 0.000 & 0 & _ & & 0 & _ & \\
\hline$* 17 / * 35$ & 1.5 & 0 & - & & 0 & - & & 1 & 0.020 & 0.004 \\
\hline$* 10 \times 2 / * 17$ & 1.5 & 0 & _- & & 0 & _- & & 1 & 0.020 & \\
\hline$* 17 \times 2 / * 29$ & 1.5 & 0 & _ & & 0 & _- & & 1 & 0.020 & \\
\hline$w t / w t$ & 2 & 28 & 0.201 & 0.232 & 60 & 0.305 & 0.255 & 9 & 0.184 & 0.143 \\
\hline$w t / * 2$ & 2 & 32 & 0.230 & 0.174 & 21 & 0.107 & 0.152 & 2 & 0.041 & 0.046 \\
\hline$w t / * 35$ & 2 & 0 & _- & 0.004 & 1 & 0.005 & 0.008 & 0 & _- & 0.008 \\
\hline$* 2 / * 2$ & 2 & 2 & 0.014 & 0.032 & 7 & 0.036 & 0.023 & 1 & 0.020 & 0.004 \\
\hline$* 2 / * 35$ & 2 & 0 & _- & & 1 & 0.005 & 0.002 & 0 & _ & \\
\hline$w t \times 2 / * 3$ & 2 & 1 & 0.007 & 0.001 & 0 & - & & 0 & - & \\
\hline$w t \times 2 / * 4$ & 2 & 0 & - & & 0 & _- & & 3 & 0.061 & \\
\hline$w t / * 10 \times 2$ & 2 & 0 & _- & & 0 & - & & 1 & 0.020 & \\
\hline
\end{tabular}


TABLE 2 (Continued)

\begin{tabular}{|c|c|c|c|c|c|c|c|c|c|}
\hline \multirow{3}{*}{ Genotype } & \multirow{3}{*}{$\begin{array}{l}\text { Activity } \\
\text { score }\end{array}$} & \multicolumn{3}{|c|}{ Mestizo } & \multicolumn{3}{|c|}{ Amerindian } & \multicolumn{2}{|r|}{ Afro-Caribbean } \\
\hline & & \multicolumn{3}{|c|}{$\mathrm{n}=139$} & \multicolumn{3}{|c|}{$\mathrm{n}=197$} & \multicolumn{2}{|r|}{$\mathrm{n}=49$} \\
\hline & & $\mathrm{n}$ & Frequency & Expected freq & $\mathrm{n}$ & Frequency & Expected freq & $\mathrm{n}$ & Frequency Expected freq \\
\hline$w t / w t x N^{+}$ & $>2$ & 5 & 0.036 & 0.028 & 4 & 0.020 & 0.010 & 1 & 0.020 \\
\hline$w t / * 2 x N^{\wedge}$ & $>2$ & 5 & 0.036 & 0.024 & 3 & 0.015 & 0.008 & 2 & 0.041 \\
\hline$w t x 5 / * 3$ & $>2$ & 1 & 0.007 & 0.001 & 0 & - & & 0 & - \\
\hline$w t x 3 / * 41$ & $>2$ & 1 & 0.007 & 0.004 & 0 & - & & 0 & - \\
\hline$* 2 \times 2 / * 2$ & $>2$ & 1 & 0.007 & 0.009 & 0 & - & & 0 & _ \\
\hline$* 2 \times 3 / * 17$ & $>2$ & 0 & - & & 0 & - & & 1 & 0.020 \\
\hline$* 2 \times 2 / * 29$ & $>2$ & 1 & 0.007 & 0.001 & 0 & _ & & 0 & 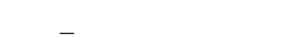 \\
\hline
\end{tabular}

n: number of subjects. ${ }^{*} \mathrm{~N}=2$ in one individual, $\mathrm{N}=3$ in one individual. ${ }^{+} \mathrm{N}=2$ in three individuals from the mestizo group, three from the Amerindian group, and in one individual from the Afro-Caribbean group; $\mathrm{N}=3$ in two individuals from the mestizo group and one from the Amerindian group. ${ }^{\wedge} \mathrm{N}=2$ in three individuals from the mestizo group, three from the Amerindian group and in two individuals from the Afro-Caribbean group; $\mathrm{N}=3$ in one individual from the mestizo group; $\mathrm{N}=4$ in one individual from the mestizo group.

examined the predicted metabolic phenotype frequencies of CYP2D6 (UMs and PMs) in three ethnic groups. The entire Costa Rican population frequency of PMs $(6 \%)$ is consistent with the Portuguese (Albuquerque et al., 2013), the Mexican-American (Casner, 2005), and the Colombian mestizo (Isaza, Henao, López, \& Cacabelos, 2000) populations. Likewise, the frequency of UMs for the Costa Rican population is similar to those reported for the Spanish population (6.1\%) (Peñas-Lledó et al., 2012).

Considering the ethnicity of the analyzed populations, the frequency of UMs in the mestizo group $(10.1 \%)$ is similar to those reported in a Spanish population $(6.1 \%)$ (Peñas-Lledó et al., 2012), those of a Mexican admixed population $(9.1 \%)$ (López, Guerrero, Jung-Cook, \& Alonso, 2005), and it is lightly greater than the percentage of UMs determined with debrisoquine in a Spanish population $(5.2 \%, \mathrm{p}=0.053)$ (Llerena et al., 2009). Moreover, the high frequency of PMs in the Costa Rican Amerindian population $(10.2 \%)$ is similar to that reported in an Amerindian population from Argentina and Paraguay (12.8\%) (Bailliet et al., 2007). Despite the small number of individuals in the Afro-Caribbean group, the frequencies of PMs and UMs are comparable to those of Brazilian populations with African ancestry (Kohlrausch et al., 2009; Silveira, Canalle, Scrideli, Queiroz, \& Tone, 2009).
Individuals carrying two inactive alleles will produce a non-functional protein. Therefore, all of them will likewise be determined as PMs in phenotyping studies. However, discordance between the identification of UMs by molecular methods and phenotype has been reported (Llerena et al., 2012; Løvlie, Daly, Molven, Idle, \& Steen, 1996), so the predicted phenotype estimation needs to be confirmed with phenotyping studies.

Variability of CYP2D6 alleles was found within this Costa Rican population, in accordance with the finding that the Costa Rican population is genetically heterogeneous (Morera et al., 2003; Morera \& Barrantes, 2004). The high frequency of PMs in the Amerindian group can mainly be accounted for by the presence of the null allele CYP2D6*4 in this population $(22.6 \%)$ at a frequency similar to those found in Amerindian populations of Argentina-Paraguay (17.8\%) (Bailliet et al., 2007). However, it is higher than those reported in Panamanian Embera (14\%) and Ngwabe (17.1\%) populations $(\mathrm{p}<0.05)$ (Jorge, Eichelbaum, Griese, Inaba, \& Arias, 1999).

Regarding reduced activity alleles, the CYP2D6*17 and CYP2D6*29 frequencies in the Afro-Caribbean population were similar to those reported for an Afro-American population (Gaedigk, Bradford, Marcucci, \& Leeder, 2002), in agreement with their African ancestry 
TABLE 3

Percentages (\%) of UMs and PMs for CYP2D6 predicted phenotypes and phenotypes in the Costa Rican population $(n=385)$ and other Latino, Amerindian and Iberian Peninsula populations previously studied

\begin{tabular}{|c|c|c|c|c|c|c|}
\hline \multirow{2}{*}{ Population } & \multirow{2}{*}{ Ancestry } & \multirow{2}{*}{$\mathrm{n}$} & \multicolumn{2}{|c|}{$\begin{array}{l}\text { Predicted } \\
\text { phenotype }\end{array}$} & Phenotype & \multirow{2}{*}{ Ref. } \\
\hline & & & $\begin{array}{l}\text { PMs } \\
(\%)\end{array}$ & $\begin{array}{l}\mathrm{UMs} \\
(\%)\end{array}$ & $\begin{array}{cc}\text { PMs } & \text { UMs } \\
(\%) & (\%)\end{array}$ & \\
\hline Argentina-Paraguay & Amerindian & 86 & 12.8 & & & (Bailliet et al., 2007) \\
\hline \multirow[t]{3}{*}{ Brazil } & African & 33 & 0 & & & (Silveira et al., 2009) \\
\hline & Mulatto & 89 & 1.1 & & & (Silveira et al., 2009) \\
\hline & Caucasian & 178 & 2.8 & & & (Silveira et al., 2009) \\
\hline \multirow[t]{2}{*}{ Brazil } & African & 87 & 3.5 & 3.5 & & (Kohlrausch et al., 2009) \\
\hline & Caucasian & 92 & 3.3 & 9.8 & & (Kohlrausch et al., 2009) \\
\hline \multirow[t]{2}{*}{ Cuba } & Caucasian & 130 & 2.3 & 6.2 & & (Llerena et al., 2012) \\
\hline & Admixed & 126 & 2.4 & 4.8 & & (Llerena et al., 2012) \\
\hline Ecuador & Admixed & 118 & 0.8 & 1.7 & & (Llerena et al., 2012) \\
\hline Mexico & Mexican-American & 50 & 6 & & 6 & (Casner, 2005) \\
\hline Mexico & Mexican-American & 264 & 2.7 & 1.1 & & (Luo, Gaedigk, Aloumanis, \& Wan, 2005) \\
\hline Mexico & Admixed & 349 & 1.7 & & & (Mendoza et al., 2001) \\
\hline Mexico & Admixed & 285 & & & 3.2 & (Mendoza et al., 2001) \\
\hline Mexico & Admixed & 243 & 2.1 & 9.1 & & (López et al., 2005) \\
\hline Mexico & Admixed & 100 & & & 10 & (López et al., 2005) \\
\hline \multirow[t]{4}{*}{ Mexico } & Amerindian & 58 & & & 0 & (Sosa-Macías et al., 2006) \\
\hline & Admixed & 88 & & & 6.8 & (Sosa-Macías et al., 2006) \\
\hline & Amerindian & 85 & 0 & & & (Sosa-Macías et al., 2006) \\
\hline & Admixed & 110 & 3.6 & & & (Sosa-Macías et al., 2006) \\
\hline Nicaragua & Admixed & 98 & 4.1 & 3.1 & & (Llerena et al., 2012) \\
\hline \multirow[t]{2}{*}{ Panama-Colombia } & Amerindian/Ngawbe & 344 & & & 4.4 & (Jorge et al., 1999) \\
\hline & Amerindian/Embera & 153 & & & 2.2 & (Jorge et al., 1999) \\
\hline Panama & Amerindian-Cuna & 51 & & & 0 & (Arias et al., 1986) \\
\hline Panama & Amerindian-Ngawbe Guaymi & 121 & & & 5.2 & (Arias et al., 1988) \\
\hline Portugal & Caucasian & 300 & 6.3 & 4.3 & & (Albuquerque et al., 2013) \\
\hline Spain & Caucasian & 925 & & & 4.9 & (Llerena, 1993) \\
\hline Spain & Caucasian & 327 & 7 & 6.1 & & (Peñas-Lledó et al., 2012) \\
\hline Spain & Caucasian & 290 & 2.4 & & & (Crescenti et al., 2007) \\
\hline Uruguay & Admixed & 302 & & & 7.3 & (Estevez, Giusti, Parrillo, \& Oxandabarat, 1997) \\
\hline Venezuela & Admixed & 100 & 3 & & & (Griman, Moran, Camargo, \& Chiurillo, 2009) \\
\hline \multirow[t]{6}{*}{ Venezuela } & Admixed & 149 & 2.01 & & & (Griman et al., 2012) \\
\hline & Amerindian/Bari & 40 & 25 & & & (Griman et al., 2012) \\
\hline & Amerindian/Panare & 46 & 0 & & & (Griman et al., 2012) \\
\hline & Amerindian/Pemon & 40 & 0 & & & (Griman et al., 2012) \\
\hline & Amerindian/Warao & 29 & 0 & & & (Griman et al., 2012) \\
\hline & Amerindian/Wayuu & 24 & 0 & & & (Griman et al., 2012) \\
\hline \multirow[t]{3}{*}{ Costa Rica } & Admixed & 139 & 1.4 & 10.1 & & This study \\
\hline & Amerindian & 197 & 10.2 & 3.6 & & \\
\hline & Afro-Caribbean & 49 & 2 & 8.2 & & \\
\hline
\end{tabular}

$\mathrm{n}=$ number of subjects; Ref.=references. 
(Bradford, 2002). Moreover, the CYP2D6*10 frequency in the Amerindian group $(0.3 \%)$ was similar to that of the Tepehuano (0\%) (SosaMacías et al., 2006, 2010) and Mapuche (1.8\%) (Muñoz et al., 1998) populations, but lower than other Amerindian populations $(7.1 \%$ and $6.9 \% ; \mathrm{p}<0.05$ ) (Bailliet et al., 2007; Jorge et al., 1999).

A limitation of this study was that the number of individuals in the Afro-Caribbean population was low $(n=49)$. Moreover, the inclusion criteria did not include ancestry informative markers analysis (AIMs). In this sense, further studies involving genetic markers of ancestry are needed in the Costa Rican population. It is necessary to remark that even though this study reports allele frequencies of CYP2D6 for Costa Ricans, they might not be representative of the population and might have been influenced by random effects.

Furthermore, the study of populations with complex ancestry such as Latin American populations comprises the fact that novel or rare variants (Fohner et al., 2013; Gaedigk et al., 2010) might appear, leading to poor metabolism or reduced function (Montané-Jaime et al., 2013). In the future, sequencing the CYP2D6 gene in these populations might be suitable to detect relevant genetic variants.

Given the percentage of UMs found in the mestizo and Afro-Caribbean population and of PMs in the Amerindian group, it might be appropriate to follow available guidelines that provide information relating to the interpretation of CYP2D6 genotype test results to guide the dosing of different drugs (Crews et al., 2012; Hicks et al., 2013). Likewise, the information provided by this study supports that it might be appropriate to consider the development of drug treatment guidelines taking into account population ethnic background, meaning specific alleles of the population tested, to improve drug safety and efficacy in Costa Rican and Latin American populations.

In conclusion, we report here for the first time the frequency of PMs (6\%) and UMs $(6.5 \%)$ in a Costa Rican population. Secondly, we found a difference between the frequency of predicted UM and PM phenotype across ethnicity in Costa Ricans.

\section{ACKNOWLEDGMENTS}

CCG was supported by a fellowship of the University of Costa Rica in the $\mathrm{PhD}$ program of the University of Extremadura. The study is part of the Research Program entitled "Genética, Ecología y Salud en los Amerindios de Costa Rica" ( $\left.{ }^{\circ} 742-93-903\right)$ and the project $\mathrm{N}^{\circ} 742-90-416$ of the University of Costa Rica. The research was supported by Gobierno de Extremadura, Consejería de Empleo, Empresa e Innovación, and Fondo Social Europeo (FSE) fellowship PD10199 (MEGN) and a grant from AEXCID 13IA002. The project was coordinated in the CEIBA.FP Consortium of the Ibero-American Network of Pharmacogenetics \& Pharmacogenomics (RIBEF): Graciela E. Moya (Buenos Aires, Argentina), Eduardo Tarazona-Santos (Belo Horizonte, Brazil), Alba P. Sarmiento (Bogotá, Colombia), Ramiro Barrantes (San José, Costa Rica), Idania Rodeiro, Luis R. Calzadilla (La Habana, Cuba), Enrique Terán (Quito, Ecuador), Rocío Ortiz-López (Nuevo León, México), Marisol López-López (Mexico City, Mexico), Martha G. Sosa-Macías (Durango, Mexico), Ronald Ramírez-Roa (León, Nicaragua), Manuela Grazina (Coimbra, Portugal), Adrián LLerena (Badajoz, Spain), Francisco E. Estévez-Carrizo (Montevideo, Uruguay).

\section{RESUMEN}

Antecedentes étnicos y polimorfismo genético del CYP2D6 en los costarricenses. El Consorcio de la Red Iberoamericana de Farmacogenética CEIBA.FP ha demostrado que existen diferencias en cuanto a CYP2D6 en las poblaciones latinoamericanas. Sin embargo, hasta ahora, se sabe poco de este gen de importancia farmacogenética en la población de Costa Rica, la cual tiene una ancestría trihíbrida. El presente estudio tiene como objetivos: determinar la frecuencia de los fenotipos extrapolados de CYP2D6 en una población costarricense y determinar si existen diferencias en cuanto a las frecuencias de metabolizadores lentos (PMs) y ultra-rápidos (UMs) entre tres grupos con distinto origen étnico. Adicionalmente, las frecuencias de PMs y UMs obtenidas en este estudio fueron comparadas 
con datos de poblaciones iberoamericanas. Por último, se pretende describir las frecuencias alélicas en los distintos grupos. En el estudio se incluyeron 385 muestras de individuos: 139 mestizos, 197 amerindios y 49 afro-caribeños. Los genotipos CYP2D6 fueron determinados por XL-PCR y PCR tiempo real. Se determinaron las variantes alélicas $* 2, * 3, * 4, * 5, * 6, * 10, * 17, * 29, * 35$ y *41. Para la población total estudiada las frecuencia de PMs y UMs fueron respectivamente $6 \%$ y $6.5 \%$. El porcentaje de individuos UMs fue mayor en la población mestiza que en la amerindia. La frecuencia de UMs varió de 3.6 a $10.1 \%$ y la de PMs de 1.4 a $10.1 \%$ en los grupos costarricenses. Las frecuencias más altas de UMs (10.1\%) y de PMs (10.2\%) se encontraron respectivamente en las poblaciones mestiza y amerindia. En conclusión, las frecuencias de UMs y PMs de CYP2D6 varían ampliamente en las poblaciones mestiza, amerindia y afro-caribeña de Costa Rica. Investigaciones futuras en la población de Costa Rica deberían orientarse a identificar nuevas variantes del CYP2D6 mediante métodos de secuenciación, así como a determinar el fenotipo de CYP2D6 con el objetivo de establecer la relación fenotipo-genotipo. Finalmente, es necesario realizar estudios adicionales que involucren marcadores genéticos de ancestría en la población costarricense.

Palabras clave: CYP2D6, Costa Rica, amerindios, afrocaribeños, mestizos, poblaciones, metabolizadores lentos, metabolizadores ultra-rápidos.

\section{REFERENCES}

Albuquerque, J., Ribeiro, C., Naranjo, M. E., Llerena, A., Grazina, M., \& CEIBA.FP Consortium. (2013). Characterization of CYP2D6 genotypes and metabolic profiles in the Portuguese population: pharmacogenetic implications. Personalized Medicine, 10(7), 709-718.

Arias, T. D., Jorge, L., Lee, D., Guerrero de Solís, N., Escobar, J., Barrantes, R., \& Inaba, T. (1986). Biotransformation of sparteine in the Cuna American Indians of Panama. Revista médica de Panamá, 11(3), 199-209.

Arias, T. D., Jorge, L. F., Lee, D., Barrantes, R., \& Inaba, T. (1988). The oxidative metabolism of sparteine in the Cuna Amerindians of Panama: absence of evidence for deficient metabolizers. Clinical Pharmacology and Therapeutics, 43(4), 456-465.

Azofeifa, J., Hahn, M., Ruiz, E., Hummerich, L., Morales, A. I., Jiménez, G., \& Barrantes, R. (2004). The STR polymorphism (AAAAT)n within the intron 1 of the tumor protein 53 (TP53) locus in 17 populations of different ethnic groups of Africa, America, Asia and Europe. Revista de Biología Tropical, 52(3), 645-657.

Bailliet, G., Santos, M. R., Alfaro, E. L., Dipierri, J. E., Demarchi, D. A., Carnese, F. R., \& Bianchi, N. O. (2007). Allele and genotype frequencies of metabolic genes in Native Americans from Argentina and Paraguay. Mutation Research, 627(2), 171-177.

Barrantes, R., Smouse, P. E., Neel, J. V., Mohrenweiser, H. W., \& Gershowitz, H. (1982). Migration and genetic infrastructure of the Central American Guaymi and their affinities with other tribal groups. American Journal of Physical Anthropology, 58(2), 201-214.

Barrantes, R. (1989). Biodemografía de las poblaciones amerindias de Costa Rica. Vínculos, 15, 59-68.

Barrantes, R., Smouse, P. E., Mohrenweiser, H. W., Gershowitz, H., Azofeifa, J., Arias, T. D., \& Neel, J. V. (1990). Microevolution in lower Central America: genetic characterization of the Chibcha-speaking groups of Costa Rica and Panama, and a consensus taxonomy based on genetic and linguistic affinity. American Journal of Human Genetics, 46(1), 63-84.

Barrantes, R. (1993a). Diversidad genética y mezcla racial en los amerindios de Costa Rica y Panamá. Revista de Biología Tropical, 41(3), 379-384.

Barrantes, R. (1993b). Estructura de poblaciones. In Evolución en el trópico: los amerindios de Costa Rica y Panamá (pp. 51-85). San José, Costa Rica: Editorial de la Universidad de Costa Rica.

Bieber, H., Bieber, S. W., Rodewald, A., \& Barrantes, R. (1996). Microevolution and genetic affinities among six Amerindian tribes of lower Central America: comparative genetic study of serum proteins. Human Biology, 68(6), 929-953.

Bradford, L. D. (2002). CYP2D6 allele frequency in European Caucasians, Asians, Africans and their descendants. Pharmacogenomics, 3(2), 229-243.

Casner, P. R. (2005). The effect of CYP2D6 polymorphisms on dextromethorphan metabolism in Mexican Americans. Journal of Clinical Pharmacology, 45(11), 1230-1235.

Crescenti, A., Mas, S., Gassó, P., Baiget, M., Bernardo, M., \& Lafuente, A. (2007). Simultaneous genotyping of CYP2D6*3, *4, *5 and *6 polymorphisms in a Spanish population through multiplex long polymerase chain reaction and minisequencing multiplex single base extension analysis. Clinical and Experimental Pharmacology \& Physiology, 34(10), 992-997.

Crews, K. R., Gaedigk, A., Dunnenberger, H. M., Klein, T. E., Shen, D. D., Callaghan, J. T., Kharasch, E. D., \& Skaar, T. C. (2012). Clinical Pharmacogenetics Implementation Consortium. Clinical Pharmacogenetics Implementation Consortium (CPIC) guidelines for codeine therapy in the context of cytochrome P450 2D6 (CYP2D6) genotype. Clinical Pharmacology and Therapeutics, 91(2), 321-326.

CYP Alleles Nomenclature Database. (2013). The Human Cytochrome P450 (CYP) Allele Nomenclature Database. Retrieved from http://www.cypalleles.ki.se/ cyp2d6.htm 
De Andrés, F., Sosa-Macías, M., Lazalde-Ramos, B. P., Naranjo, M. E. G., Tarazona-Santos, E., Llerena, A., \& CEIBA.FP Consortium of the Ibero-American Network of Pharmacogenetics and Pharmacogenomics RIBEFa. (2013). Evaluation of drug-metabolizing enzyme hydroxylation phenotypes in Hispanic populations: the CEIBA cocktail. Drug Metabolism and Drug Interactions, 28(3), 135-146. doi:10.1515/ dmdi-2013-0020

Dorado, P., Cáceres, M. C., Pozo-Guisado, E., Wong, M. L., Licinio, J., \& Llerena, A. (2005). Development of a PCR-based strategy for CYP2D6 genotyping including gene multiplication of worldwide potential use. BioTechniques, 39(4), 571-574.

Dorado, P., Heras, N., Machín, E., Hernández, F., Teran, E., \& Llerena, A. (2012). CYP2D6 genotype and dextromethorphan hydroxylation phenotype in an Ecuadorian population. European Journal of Clinical Pharmacology, 68(5), 637-644.

Estevez, F., Giusti, M., Parrillo, S., \& Oxandabarat, J. (1997). Dextromethorphan O-demethylation polymorphism in the Uruguayan population. European Journal of Clinical Pharmacology, 52(5), 417-418.

Fohner, A., Muzquiz, L. I., Austin, M. A., Gaedigk, A., Gordon, A., Thornton, T., Rieder, M. J., Pershouse, M. A., Putnam, E. A., Howlett, K., Beatty, P., Thummel, K. E., \& Woodahl, E. L. (2013). Pharmacogenetics in American Indian populations: analysis of CYP2D6, CYP3A4, CYP3A5, and CYP2C9 in the Confederated Salish and Kootenai Tribes. Pharmacogenetics and Genomics, 23(8), 403-414. doi:10.1097/ FPC.0b013e3283629ce9

Gaedigk, A., Bradford, L., Marcucci, K., \& Leeder, J. (2002). Unique CYP2D6 activity distribution and genotype-phenotype discordance in black Americans. Clinical Pharmacology and Therapeutics, 72(1), 76-89.

Gaedigk, A., Simon, S. D., Pearce, R. E., Bradford, L. D., Kennedy, M. J., \& Leeder, J. S. (2008). The CYP2D6 activity score: translating genotype information into a qualitative measure of phenotype. Clinical Pharmacology and Therapeutics, 83(2), 234-242.

Gaedigk, A., Isidoro-García, M., Pearce, R. E., Sánchez, S., García-Solaesa, V., Lorenzo-Romo, C., GonzalezTejera, G., \& Corey, S. (2010). Discovery of the nonfunctional CYP2D6 31 allele in Spanish, Puerto Rican, and US Hispanic populations. European Journal of Clinical Pharmacology, 66(9), 859-864.

González, I., Peñas-Lledó, E. M., Pérez, B., Dorado, P., Alvarez, M., \& Llerena, A. (2008). Relation between CYP2D6 phenotype and genotype and personality in healthy volunteers. Pharmacogenomics, 9(7), 833-840.

Griman, P., Moran, Y., Camargo, M., \& Chiurillo, M. (2009). Caraterización de las variantes alélicas del citocromo CYP2D6 en la población de la región centroccidental de Venezuela. Acta Biológica Colombiana, 14(1), 195-202.

Griman, P., Moran, Y., Valero, G., Loreto, M., Borjas, L., \& Chiurillo, M. A. (2012). CYP2D6 gene variants in urban/admixed and Amerindian populations of Venezuela: pharmacogenetics and anthropological implications. Annals of Human Biology, 39(2), 137-142.

Herrmann, F., Salazar-Sánchez, L., Schuster, G., Jiménez-Arce, G., Grimm, R., Gómez, X., Chavez, V., \& Schrøder, W. (2002). Molecular markers in the genes for FV (FVL. FV HR2, FVIVS 16), MTHFR, prothrombin and ACE in Amerindians and Africans from Costa Rica. Gene Diagnosis of Inherited Bleeding Disorders, 203-220.

Hicks, J. K., Swen, J. J., Thorn, C. F., Sangkuhl, K., Kharasch, E. D., Ellingrod, V. L., Skaar, T. C., Müller, D. J., Gaedigk, A., \& Stingl, J. C. (2013). Clinical Pharmacogenetics Implementation Consortium guideline for CYP2D6 and CYP2C19 genotypes and dosing of tricyclic antidepressants. Clinical Pharmacology and Therapeutics, 93(5), 402-408. doi:10.1038/ clpt.2013.2

Ingelman-Sundberg, M. (2005). Genetic polymorphisms of cytochrome P450 2D6 (CYP2D6): clinical consequences, evolutionary aspects and functional diversity. The Pharmacogenomics Journal, 5(1), 6-13.

Isaza, C. A., Henao, J., López, A. M., \& Cacabelos, R. (2000). Isolation, sequence and genotyping of the drug metabolizer CYP2D6 gene in the Colombian population. Methods and Findings in Experimental and Clinical Pharmacology, 22(9), 695-705.

Jorge, L. F., \& Arias, T. D. (1995). Human biodiversity and its effects on the pharmacological variability: CYP2D6 and NAT2 enzymes in Amerind populations of Panama, Colombia and Costa Rica. Revista Médica de Panamá, 20(3), 98-107.

Jorge, L. F., Eichelbaum, M., Griese, E. U., Inaba, T., \& Arias, T. D. (1999). Comparative evolutionary pharmacogenetics of CYP2D6 in Ngawbe and Embera Amerindians of Panama and Colombia: role of selection versus drift in world populations. Pharmacogenetics, 9(2), 217-228.

Kohlrausch, F. B., Gama, C. S., Lobato, M. I., Belmontede-Abreu, P., Gesteira, A., Barros, F., Carracedo, A., \& Hutz, M. H. (2009). Molecular diversity at the CYP2D6 locus in healthy and schizophrenic southern Brazilians. Pharmacogenomics, 10(9), 1457-1466.

Llerena, A., Edman, G., Cobaleda, J., Benítez, J., Schalling, D., \& Bertilsson, L. (1993). Relationship between personality and debrisoquine hydroxylation capacity. Suggestion of an endogenous neuroactive substrate or product of the cytochrome P4502D6. Acta Psychiatrica Scandinavica, 87(1), 23-28. 
Llerena, A., Dorado, P., \& Peñas-Lledó, E. M. (2009). Pharmacogenetics of debrisoquine and its use as a marker for CYP2D6 hydroxylation capacity. Pharmacogenomics, 10(1), 17-28.

Llerena, A., Dorado, P., Ramírez, R., González, I., Alvarez, M., Peñas-Lledó, E. M., Pérez, B., \& Calzadilla, L. R. (2012). CYP2D6 genotype and debrisoquine hydroxylation phenotype in Cubans and Nicaraguans. The Pharmacogenomics Journal, 12(2), 176-183.

Llerena, A., Dorado, P., Ramírez, R., Calzadilla, L. R., Peñas-Lledó, E., Alvarez, M., Naranjo, M. E., González, I., Pérez, B., \& CEIBA Consortium of the Ibero-American Network of Pharmacogenetics \& Pharmacogenomics RIBEF. (2013). CYP2D6 $-1584 \mathrm{C}>\mathrm{G}$ promoter polymorphism and debrisoquine ultrarapid hydroxylation in healthy volunteers. Pharmacogenomics, 14(16), 1973-1977. doi:10.2217/ pgs.13.181

López, M., Guerrero, J., Jung-Cook, H., \& Alonso, M. E. (2005). CYP2D6 genotype and phenotype determination in a Mexican Mestizo population. European Journal of Clinical Pharmacology, 61(10), 749-754.

Løvlie, R., Daly, A. K., Molven, A., Idle, J. R., \& Steen, V. M. (1996). Ultrarapid metabolizers of debrisoquine: characterization and PCR-based detection of alleles with duplication of the CYP2D6 gene. FEBS Letters, 392(1), 30-34.

Luo, H. R., Gaedigk, A., Aloumanis, V., \& Wan, Y. J. Y. (2005). Identification of CYP2D6 impaired functional alleles in Mexican Americans. European Journal of Clinical Pharmacology, 61(11), 797-802.

Madrigal, L. (2006). The Afro-Caribbean population in Limón, Costa Rica. In Human Biology of AfroCaribbean populations (pp. 176-185). New York, USA: Cambridge University Press.

Mendoza, R., Wan, Y. J., Poland, R. E., Smith, M., Zheng, Y., Berman, N., \& Lin, K. M. (2001). CYP2D6 polymorphism in a Mexican American population. Clinical Pharmacology and Therapeutics, 70(6), 552-560.

Montané-Jaime, L. K., Lalla, A., Steimer, W., \& Gaedigk, A. (2013). Characterization of the CYP2D6 gene locus and metabolic activity in Indo- and Afro-Trinidadians: discovery of novel allelic variants. Pharmacogenomics, 14(3), 261-276. doi:10.2217/pgs.12.207

Morera, B., Barrantes, R., \& Marin-Rojas, R. (2003). Gene admixture in the Costa Rican population. Annals of Human Genetics, 67(1), 71-80.

Morera, B., \& Barrantes, R. (2004). Is the Central Valley of Costa Rica a genetic isolate? Revista de Biología Tropical, 52(3), 629-644.

Muñoz, S., Vollrath, V., Vallejos, M. P., Miquel, J. F., Covarrubias, C., Raddatz, A., \& Chianale, J. (1998). Genetic polymorphisms of CYP2D6, CYP1A1 and
CYP2E1 in the South-Amerindian population of Chile. Pharmacogenetics, 8(4), 343-351.

Peñas-Lledó, E. M., Dorado, P., Pacheco, R., González, I., \& Llerena, A. (2009). Relation between CYP2D6 genotype, personality, neurocognition and overall psychopathology in healthy volunteers. Pharmacogenomics, 10(7), 1111-1120.

Peñas-Lledó, E. M., Dorado, P., Agüera, Z., Gratacós, M., Estivill, X., Fernández-Aranda, F., \& Llerena, A. (2012). CYP2D6 polymorphism in patients with eating disorders. The Pharmacogenomics Journal, 12(2), 173-175.

Reich, D., Patterson, N., Campbell, D., Tandon, A., Mazieres, S., Ray, N., Parra, M. V., Rojas, W., Duque, C., Mesa, N., García, L. F., Triana, O., Blair, S., Maestre, A., Dib, J. C., Bravi, C. M., Bailliet, G., Corach, D., Hünemeier, T., Bortolini, M. C., Salzano, F. M., Petzl-Erler, M. L., Acuña-Alonzo, V., AguilarSalinas, C., Canizales-Quinteros, S., Tusié-Luna, T., Riba, L., Rodríguez-Cruz, M., López-Alarcón, M., Coral-Vázquez, R., Canto-Cetina, T., Silva-Zolezzi, I., Fernández-López, J. C., Contreras, A. V., JiménezSánchez, G., Gómez-Vázquez, M. J., Molina, J., Carracedo, A., Salas, A., Gallo, C., Poletti, G., Witonsky, D. B., Alkorta-Aranburu, G., Sukernik, R. I., Osipova, L., Fedorova, S. A., Vasquez, R., Villena, M., Moreau, C., Barrantes, R., Pauls, D., Excoffier, L., Bedoya, G., Rothhammer, F., Dugoujon, J. M., Larrouy, G., Klitz, W., Labuda, D., Kidd, J., Kidd, K., Di Rienzo, A., Freimer, N. B., Price, A. L., \& RuizLinares, A. (2012). Reconstructing Native American population history. Nature, 488(7411), 370-374.

Rodeiro, I., Remírez-Figueredo, D., García-Mesa, M., Dorado, P., Llerena, A., \& CEIBA.FP Consortium of the Ibero-American Network of Pharmacogenetics and Pharmacogenomics RIBEF. (2012). Pharmacogenetics in Latin American populations: regulatory aspects, application to herbal medicine, cardiovascular and psychiatric disorders. Drug Metabolism and Drug Interactions, 27(1), 57-60.

Ruiz-Narváez, E. A., Santos, F. R., Carvalho-Silva, D. R., Azofeifa, J., Barrantes, R., \& Pena, S. D. J. (2005). Genetic variation of the $\mathrm{Y}$ chromosome in Chibchaspeaking Amerindians of Costa Rica and Panama. Human Biology, 77(1), 71-91.

Sans, M. (2000). Admixture studies in Latin America: from the 20th to the 21st century. Human Biology, 72(1), 155-177.

Santos, M., Ward, R. H., \& Barrantes, R. (1994). mtDNA variation in the Chibcha Amerindian Huetar from Costa Rica. Human Biology, 66(6), 963-977.

Segura-Wang, M., Raventós, H., Escamilla, M., \& Barrantes, R. (2010). Assessment of genetic ancestry and population substructure in Costa Rica by analysis of 
individuals with a familial history of mental disorder. Annals of Human Genetics, 74(6), 516-524.

Silveira, V. D. S., Canalle, R., Scrideli, C. A., Queiroz, R. G. de P., \& Tone, L. G. (2009). Polymorphisms in genes encoding drugs and xenobiotic metabolizing enzymes in a Brazilian population. Biomarkers: Biochemical Indicators of Exposure, Response, and Susceptibility to Chemicals, 14(2), 111-117.

Sosa-Macías, M., Elizondo, G., Flores-Pérez, C., FloresPérez, J., Bradley-Alvarez, F., Alanis-Bañuelos, R. E., \& Lares-Asseff, I. (2006). CYP2D6 genotype and phenotype in Amerindians of Tepehuano origin and Mestizos of Durango, Mexico. Journal of Clinical Pharmacology, 46(5), 527-536.

Sosa-Macías, M., Dorado, P., Alanis-Bañuelos, R. E., Llerena, A., \& Lares-Asseff, I. (2010). Influence of CYP2D6 deletion, multiplication, $-1584 \mathrm{C}-->\mathrm{G}, 31 \mathrm{G}-$ ->A and 2988G-->a gene polymorphisms on dextromethorphan metabolism among Mexican tepehuanos and mestizos. Pharmacology, 86(1), 30-36.

Thompson, E. A., Neel, J. V., Smouse, P. E., \& Barrantes, R. (1992). Microevolution of the Chibcha-speaking peoples of lower Central America: rare genes in an Amerindian complex. American Journal of Human Genetics, 51(3), 609-626.

Wang, S., Lewis, C. M., Jakobsson, M., Ramachandran, S., Ray, N., Bedoya, G., Rojas, W., Parra, M. V., Molina, J. A., Gallo, C., Mazzotti, G., Poletti, G., Hill, K., Hurtado, A. M., Labuda, D., Klitz, W., Barrantes, R., Bortolini, M. C., Salzano, F. M., Petzl-Erler, M. L., Tsuneto, L. T., Llop, E., Rothhammer, F., Excoffier, L., Feldman, M. W., Rosenberg, N. A., \& RuizLinares, A. (2007). Genetic variation and population structure in native Americans. PLoS Genetics, 3(11), e185.

Wang, S., Ray, N., Rojas, W., Parra, M. V., Bedoya, G., Gallo, C., Poletti, G., Mazzotti, G., Hill, K., Hurtado, A. M., Camrena, B., Nicolini, H., Klitz, W., Barrantes, R., Molina, J. A., Freimer, N. B., Bortolini, M. C., Salzano, F. M., Petzl-Erler, M. L., Tsuneto, L. T., Dipierri, J. E., Alfaro, E. A., Bailliet, G., Bianchi, N. O., Llop, E., Rothhammer, F., Excoffier, L., \& RuizLinares, A. (2008). Geographic patterns of genome admixture in Latin American Mestizos. PLoS Genetics, 4(3), e1000037. 
